\title{
KEJAHATAN DAN CAMPUR TANGAN TUHAN (Sebuah Tinjauan Teodesi dan Teologi Islam)
}

\author{
Syafieh \\ Dosen Fakultas Ushuluddin, Adab dan Dakwah IAIN Langsa \\ syafiehyanti@gmail.com
}

\begin{abstract}
This article discusses God 's omniscience and interference in the theological and Islamic's theological perspectives. Theodical problem that centered on causality and the administration of God since the days of Greece God presented as a defendant. Berger uses theodicy concept to give meaning to the suffering experienced by humans in the world, while simultaneously promising happiness "in the world there". In this connection religion is clearly a force of alienation. Crime and suffering as a privacy are always present in reality and life. While Islamic's theological reject the theodetic concept, according to Muttahharri, that on the plains of phenomena there is no "real evil" or "true goodness", while on plain noumena there is only one essence, namely goodness, because the substance of evil is truly pure nothingness.
\end{abstract}

Keywords:Theodicy, Religion, Goodness, Evil

\begin{abstract}
Abstrak
Artikel ini membahas kemahatahuan Tuhan dan campur tangan dalam perspektif teologis dan teologis Islam. Masalah teodis yang berpusat pada kausalitas dan administrasi Tuhan sejak zaman Yunani dihadirkan Tuhan sebagai tergugat. Berger menggunakan konsep teodisi untuk memberi makna pada penderitaan yang dialami manusia di dunia, sekaligus menjanjikan kebahagiaan "di dunia sana". Dalam hubungan ini, agama jelas merupakan kekuatan alienasi. Kejahatan dan penderitaan sebagai privasi selalu hadir dalam kenyataan dan kehidupan. Sedangkan teologis Islam menolak konsep teodetik, menurut Muttahharri, bahwa di dataran fenomena tidak ada "kejahatan sejati" atau "kebaikan sejati", sedangkan pada noumena polos hanya ada satu esensi, yaitu kebaikan, karena substansi kejahatan adalah ketiadaan yang benar-benar murni.
\end{abstract}

Kata Kunci : Teologi, Religius, Kebaikan, Kejahatan 
Syafieh

\section{Pendahuluan}

Teodisi dalam ranah dan kajian filsafat boleh dikatakan kurang mendapat perhatian para filsuf dibandingkan dengan metafisika misalnya. Bahkan cenderung terlupakan. Pada hal harus diakui materi yang dikandungnya sangat mendasar dan penting dalam upaya pemahaman manusia. Spesifikasi teodisi terletak pada penekanan atas kausalitas dan penyelenggaraan atau proviodensi Tuhan yang merupakan bagian substansial apabila mempercakapkan manusia. Problem tentang teodisi seumur dengan manusia itu sendiri. Konstatsi ini sejalan dengan paham kreasionisme lebih-lebih setelah buah pengetahuan baik dan buruk dimakan oleh Adam. Pelanggaran perintah Tuhan adalah awal dari teodisi yang dimaksudkan.

Keburukan (evil) mencoreng wajah kosmikal realitas termasuk mahluk lain Di balik peristiwa teoditik tersebut kejahatan dalam tataran fisik manusia tereksplisitkan. Segalanya berantakan. Demikian juga kejahatan dalam ranah moral selamanya akrab dengan manusia. Ketidak-adilan menjadi pemandangan sehari-hari di setiap zaman. Singkatnya kejahatan tetap bersimaharajalela.

Salah satu tantangan yang cukup berat bagi eksistensi agama datang dari problem kejahatan yang dipandang oleh sebagian filosof sebagai bukti lemahnya eksistensi agama atau Tuhan. Sebagian orang memandang fakta kejahatan sebagai bukti tidak adanya Tuhan atau agama, dan ada juga sebaliknya, yang memandang kejahatan tidak bertentangan dengan eksistensi Tuhan atau agama.Theodecy secara sederhana saya maknai sebagai paham yang menolak kehadiran Tuhan (dan karenanya juga agama) oleh sebab merajalelanya kejahatan, kemaksiatan, bencana, dan sejenisnya. Logika argumentasi yang dibangun adalah bahwa jikalau Tuhan ada, tidaklah mungkin Tuhan membiarkan keadaan dan kejadian yang menistakan dan merugikan manusia tersebut berlangsung, terusmenerus lagi. Bukankah Tuhan, dalam pandangan orang-orang theistik/beragama, adalah sosok yang maha baik dan menghendaki kebaikan bagi manusia? Bukankah Tuhan berpihak pada segala sesuatu yang baik?

Bagaimana kita menjelaskan peristiwa bencana dari sudut pandang teologis? Sungguh tidak mudah dan tidak sederhana menjelaskannya. Bagaimana manusia memahami keadilan dan kebenaran Allah dalam setiap bencana yang terjadi atas dirinya? Pertanyaan ini yang dikaitkan dengan tema theodecy, merupakan pertanyaan klasik yang terus menerus dipertanyakan di setiap waktu dan tempat.Artikel ini akan membahas tentang kejahatan dan campur tangan Tuhan dalam perspekttif teodesi dan teologi Islam. Suatu kesulitan yang dihadapi oleh pemakalah adalah ketika menghubungkan antara konsep teodisi yang berorientasi pada teologis rasionalis dengan konsep teologi Islam yang berorientasi pada teks. Sehingga saya sadari makalah ini masih terjebak pada tataran teologis dari pada sosiologis dan antropologis. 
Kejahatan dan Campur Tangan Tuhan...

\section{Defenisi Teodisi}

Secara etimologi, teodisi berasal dari bahasa Yunani "theos"berarti tuhan dan "dike", artinya keadilan, yang merupakan studiteologis filosofis yang mencoba untuk membenarkan Allah (sebagianbesar dalam monoteistik) dan bersifat omni-kebajikan (semuamencintai). Lorens Bagus, penulis Kamus Filsafat, memberikan beberapa pengertian untuk istilah ini. Pertama, teodisi diartikan sebagai ilmu yang berusaha membenarkan cara-cara (jalanjalan) Allah bagi manusia. Kedua, teodisi adalah sebuah usaha untuk mempertahankan kebaikan dan keadilan Allah ketika Allah menakdirkan atau membiarkan suatu kejahatan moral dan alamiah maupun penderitaan manusia. Ketiga, usaha untuk membuat kemahakuasaan dan kemaharahiman Allah cocok dengan eksistensi kejahatan. Dengan demikian, teodisi merupakan satu upaya untuk mempertahankan, atau bahkan "membela" pemahaman kita tentang Allah (khususnya dalam hal ini kebenaran dan keadilan-Nya), ketika realita atau fakta yang dihadapi membuat kita mempertanyakan atau menggugatnya (Bagus 2002:1089).

Istilah ini dimunculkan pada tahun 1710 oleh filsuf JermanGottfried Leibniz dalam sebuah karya berbahasa Prancis dan diterjemahkan kedalam bahasa Inggris oleh E.M Huggard berjudulTheodicy:Essays on The Goodness of God, the Freedom of Man and the Origin of Evil (Teodisi: Esai tentang Kebaikan Tuhan, Kebebasan Manusiadan Keaslian sifat Setan) (Freiherr von Gottfried Wilhelm Leibniz, 2007).Sebuah karya yang dimaksudkan untuk mancari pemecahan masalah tentang penyelenggaran Tuhan di dunia, yakni antitesa antara adanya Tuhan yang tak terhingga baiknya dengan kejahatan di dunia ini (Leahy 1993:318). stilah teodise dipertahankan disamping istilah filsafat agama (philoshophy of religion) dan filsafat ketuhanan (Philoshophy of God), karena istilah ini secara teknis kefilsafatan bersifat netral dan universal. Dalam membahas masalah ketuhanan, teodise dapat mempresentasikan kesimpulan tentang Tuhan: baik sebagai ada mutlak (God as The Absolute being), atau meminjam istilah Blaise Pascal sebagai "Ie dieu des Philosophes et des Savant" (Tuhan para filosof dan ilmuwan). Teodise pun dapat mempresentasikan Tuhan sebagai "wujud Personal" (God a Personal Spirit), yang diistilahkan oleh Pascal dengan "Ie dieu des d`Abraham, d'Isaac et de Jacob” (Tuhan Ibrahim, Ishak, dan Ya`kub).

Lebih tegas dapat dikatakan, orientasi pembahasan teodise tentang wujud Tuhan hanya berangkat dari aspek eksistensialitas-Nya(Berkhof 1981:43), artinya pembahasan hanya diarahkan pada sejauh mana keberadaan Tuhan dapat ditangkap oleh akal pikiran dengan menggunakan dan mempertimbangkan data-data ketuhanan yang konkrit dan terbuka bagi semua orang beragama atau tidak (Leahy 1993:24).

Secara tradisional menurut McCloskey, permasalahan teodisi muncul secara filosofis karena adanya kontradiksi yang memerlukan penegasan bahwa Tuhan sebagai Pencipta Yang Maha Sempurna termasuk pencipta 
kejahatan(McCloskey 1974:1). Kontradiksi dimaksud adalah keadaan di mana kita dihadapkan pada keimanan bahwa Tuhan adalah Maha Kuasa, Maha Adil, Maha Mengetahui, namun pada sisi lain, kita menyaksikan beragam kejahatan dalam kehidupan. Keadaan seperti ini, sepintas memang bisa membawa kepada suatu pembenaran pemikiran, dalam bentuk pertanyaan jika Tuhan memang Maha Adil dan Maha Sempurna mengapa dalam ciptaan-Nya masih menunjukkan kekurangsempurnaan seperti adanya bencana alam, penyakit, kemiskinan, kekafiran dan sebagainya(Schneider, Laurel C. 2008:62). Bukankah keadaan ini bisa disebut sebagai suatu kontradiksi dalam doktrin keimanan tersebut.

Bagi kelompok teisme tradisional, memandang bahwa Tuhan tetap sebagai yang Maha Kuasa, Maha Mengetahui dan Maha Sempurna, meskipun ada kejahatan di dunia. Namun, jika disadari bahwa wujud yang memiliki kebaikan itu pasti akan mengeliminir kejahatan tersebut, dan sejatinya tidak ada batasan bagi wujud yang Maha Kuasa untuk melakukan apa saja, termasuk kejahatan itu sendiri. Itu sebabnya, McCloskey merasa kesulitan untuk mengaitkan hubungan antara problem kejahatan dengan keadilan Tuhan. Bahkan, ia menyebutnya sebagai suatu misteri.

Ia menyatakan: "If God does not exist, where does good comefrom? If he does exist, where does evil comefrom? If God is the source of good, can he also be the source of evil? Evil exists and God exists. Their coexistence is a mystery." (Jika Tuhan tidak ada, dari mana asal kebaikan? Jika Dia benar-benar ada, dari mana asal kejahatan? Jika Tuhan adalah sumber kebaikan, dapatkah Dia juga menjadi sumber kejahatan?...Kejahatan ada dan Tuhan ada. Koeksistensi keduanya adalah suatu misteri) (McCloskey 1974:2).

Dalam tradisi pemikiran Islam, problem kejahatan ini muncul berkaitan dengan pembahasan tentang keadilan Tuhan. Berbagai aliran pemikiran memiliki pandangan dan penafsiran tersendiri sesuai dengan prinsip mereka masing-masing. Namun, mereka berbeda dari para filsuf maupun pemikir Barat yang cenderung mendiskreditkan Tuhan. Bagi para filsuf muslim, apalagi teolog, apapun aliran pemikirannya, orientasi mereka dalam membahas masalah ini adalah justru untuk memelihara kemahasucian (tanzih) dan kemahaesaan (tauhid) Tuhan (Nasution 1991:3234).

Jika ditelusuri secara historis, munculnya pemikiran filosofis dalam Islam senantiasa berdasarkan pada prinsip tauhid. Asy'ariah misalnya, suatu aliran pemikiran yang banyak diikuti kaum Sunni, tidak mengakui keadilan Tuhan sebagai masalah kepercayaan, sehingga mereka menolak keadilan itu sebagai tolok ukur perbuatan Tuhan (Bakar 1994:11-12). Bagi mereka, penetapan keadilan untuk perbuatan Tuhan itu sama halnya dengan membatasi kehendak-Nya. Bagi kelompok Asy'ariah, makna keadilan 
tidak memiliki hakikat apapun kecuali bahwa semua yang dilakukan Allah adalah adil. Dengan kata lain, keadilan bukan matrik bagi perbuatan Allah melainkan perbuatanNya lah yang menjadi tolok ukur bagi keadilan (Muthahhari 1997:17-18).

Selain itu, Mu'tazilah dan Syi'ah yang berseberangan dengan Asy'ariah memang menjadikan keadilan Tuhan sebagai prinsip pemikiran. Mereka mempercayai bahwa keadilan ini merupakan dasar bagi perbuatan Tuhan, dalam mengatur alam maupun menegakkan hukum-hukum-Nya. Bagi Mu'tazilah dan Syi'ah, keadilan memiliki hakikatnya sendiri. Sepanjang Allah Maha bijak dan adil, Dia akan melaksanakan perbuatan-Nya berdasarkan kriteria keadilan. Makna adil bagi Allah, seperti dituturkan oleh Qadhi Abdul Jabbar, bahwa semua perbuatan-Nya bersifat baik; Tuhan tidak akan pernah berbuat jahat atau buruk, dan tidak melupakan apa yang wajib dikerjakannya. Artinya, Tuhan tidak akan berdusta, tidak bersikap zalim, tidak menyiksa anak-anak orang kafir lantaran dosa orang tua mereka, tidak menurunkan mukjizat pada pendusta, dan tidak memberi beban yang tidak dapat dipikul oleh manusia.

Dengan kata lain, bagi Mu'tazilah, adanya kejahatan di dunia ini bukan dari Allah. Allah tidak berbuat buruk karena perbuatan buruk itu timbul hanya dari wujud yang tidak sempurna sedang Dia bersifat Maha Sempurna (Al-Jabbar 1965:313). Pernyataan bahwa semua perbuatan Tuhan bersifat baik, menurut Mu'tazilah, belum cukup untuk mengekspresikan kemahabaikan-Nya. Atas dasar itu, mereka mengajarkan konsep al-salah wa al-aslah, suatu ajaran yang menegaskan bahwa wajib bagi Tuhan memberikan yang baik bahkan yang terbaik bagi manusia. Konskuensinya, kejahatan yang terjadi di dunia bukan dari Tuhan.

Manakala kita melihat suatu kejahatan, bencana alam misalnya, bukan merupakan manifestasi kehendak dan perbuatan-Nya tetapi sebagai akibat dari perbuatan manusia atau dinamika alam itu sendiri ketika tidak sejalan dengan hukum alam (sunnatullah) yang melekat pada dirinya (Nasution 1986:54). Menurut keyakinan Mu'tazilah, segala sesuatu di alam semesta ini telah diciptakan Allah lengkap dengan dinamika dan hukum "keseimbangan" pada dirinya masing-masing. Setiap persinggungan antara satu dengan yang lain akan memberikan akibat positif atau negatif.

Dengan demikian, pemikiran Mu'tazilah maupun Syiah, sebagaimana Asy'ariyah, tetap berlandaskan tauhid dan bertujuan untuk mensucikan Tuhan. Bagi mereka, keburukan atau kejahatan bukan berasal dari Tuhan Yang Maha Sempurna melainkan implikasi dari dinamika dan interaksinya dengan hukum yang melekat pada sesuatu itu (Al-Baghdadi n.d.:95). Jika dikatakan bahwa mati adalah takdir Tuhan, maka artinya mati merupakan salah satu hukum-Nya yang berlaku bagi setiap makhluk hidup.

Dengan kata lain, setiap yang hidup mesti akan mengalami mati. Persoalannya hanya terletak pada masalah sebab dan waktu, yakni sebab 
apa yang akan mengantarkan suatu makhluk hidup menuju kematiannya. Sebab kematian bisa bersifat eksternal atau internal. Sebab eksternal berkaitan dengan pola interaksi makhluk hidup dengan sesuatu di luar dirinya, sedang sebab internal adalah hukum-hukum yang membatasi kejadiannya, misalnya adalah faktor usia. Jadi, mati pada dataran fenomenalnya hanyalah merupakan akibat dari rangkaian sebab-sebab yang ada.

\section{Agama dalam Perspektif Sosiologis}

Secara umum agama adalah sistem kepercayaan yang dianut oleh setiap orang berdasarkan keyakinan mereka masing-masing. Agama merupakan suatu kekuatan yang berpengaruh dan paling dirasakan dalam kehidupan manusia. Agama mempengaruhi manusia dalam segala aspek kehidupan. Agama mengajarkan manusia untuk percaya dan takut akan Tuhan serta mengajarkan bagimana manusia bertingkah laku yang baik dan benar.

Pada dasarnya semua agama itu sama, yakni sama-sama mengajarkan kita bagaimana memuji dan menyembah Tuhan serta menjalankan perintah dan menjauhi setiap larangannya. Agama juga merupakan petunjuk arah terhadap adanya kehidupan yang terjadi setelah adanya kematian.Agama disini menjelaskan bahwa ternyata masih ada kehidupan lain setelah adanya kematian.Oleh karena itu agama mengajarkan kita bagaimana bertingkah laku agar memperoleh kehidupan yang kekal setelah terjadinya kematian tersebut.

Tetapi tidak bisa dipungkiri bahwa di dalam kehidupan beragama ini masih ada terdapat sifat manusia yang fanatik terhadap agama lain. Mereka selalu membanding-bandingkan agama mereka sendiri dengan agama orang lain dan menganggap bahwa agama merekalah yang benar sedangkan agama yang lain itu tidak benar.

Di dalam perspektif sosiologis berpendapat bahwa alasan seseorang memilih agama tertentu tidak hanya didasarkan pada nilai-nilai kebenaran yang terkandung di dalam agama tertentu melainkan juga karena faktorfaktor lain. Misalnya karena faktor wilayah dan suku, seperti yang terdapat di Indonesia. Dimana pada umumnya orang-orang Aceh beragama Islam, orang-orang Batak beragama Kristen dan orang-orang Flores beragama Katholik.

Terkadang seseorang menganut agama tertentu bukan karena pertimbangan-pertimbangan pribadi setelah mempertimbangkan antara agama yang satu dengan agama yang lainnya, melainkan karena dia sudah terlahir di dalam wilayah itu. Artinya bahwa seseorang menganut suatu agama tertentu karena mengikuti agama yang telah dianut oleh orang tua mereka.Hal ini menunjukkan bahwa agama itu diturunkan oleh orang tua terhadap anak mereka. 
Meskipun agama itu berasal dari kepercayaan yang dianut oleh orang tua yang juga diturunkan kepada anaknya, ternyata masih ada kita jumpai dalam kehidupan bermasyarakat dimana dalam sebuah keluarga terdapat dua keyakinan yang berbeda. Misalnya ayahnya beragama kristen dan ibunya beragama islam.

Dimana pada saat mereka menikah masing-masing dari mereka tetap mempertahankan agamanya masing-masing. Sehingga pada akhirnya mereka menikah dengan kedua ajaran agama yang mereka anut. Pertama mereka menikah dengan tata cara yang ada dalam agama kristen dan selanjutnya berdasarkan tata cara yang ada dalam agama Islam. Dan ketika mereka telah memiliki anak,mereka mengatakan kepada anaknya bahwa anak-anak mereka bebas memilih agama mana yang akan mereka anut. Apakah mereka akan menganut agama yang sama seperti ayahnya ataukah menganut agama yang sama seperti ibunya.

Meskipun mereka hidup dengan perbedaan keyakinan, ternyata mereka bisa menjaga dan menghargai agama mereka satu sama lain. Dimana ketika ayahnya berdoa maka ibunya akan menghargainya. Sebaliknya ketika ibunya sembahyang dan berpuasa maka ayahnya juga menghargainya. Dalam hal ini mereka ternyata bisa tetap hidup rukun seperti orang-orang lainnya meskipun dengan dua keyakian yang berbeda dalam satu rumah.

Sebenarnya hal ini memang ada salahnya juga. Seharusnya seseorang yang hidup dalam sebuah keluraga menganut satu kepercayaan saja.Agar anak mereka juga nantinya tidak bingung-bingung apakah harus mengikut agama yang dipercayai ayah ataukah ibu. Dengan demikian maka akan lebih tercipta rasa kenyamananan dalam sebuah keluarga tersebut.

Dalam mendefenisikan agama, para ilmuan sosial biasanya menggunakan dua macam defenisi yang bisa melengkapi satu sama lain, yakni defenisi subtantif dan defenisi fungsional. Defenisi subtantif berusaha menjelaskan tentang seperti apa itu agama.Artinya dalam hal ini agama dijelaskan seperti apa kenyataannya dan kebenarannya sesuai dengan batas-batas dan kategori-kategori yang membedakannya dengan yang bukan agama. Sedangkan definisi agama secara fungsional menekankan kepada fungsi agama yang harus dijalankan sebagaimana mestinya dan tidak mementingkan isi dari kepercayaan dan praktik keagamaan.

Artinya disini menjelaskan tentang apa yang seharusnya dibuat dan dilakukan oleh agama untuk seorang individu,kelompok atau masyarakat. Bukan apa yang yang dilakukan oleh seorang individu, kelompok ataupun masyarakat terhadap agama. Dimana dalam hal ini juga menjelaskan bahwa isi dari kepercayaan dan praktik keagamaan tidaklah terlalu penting dibandingkan dengan konsekuensi-konsekuensi dari agama itu untuk kehidupan masyarakat.

Tokoh sosiologi yang memberikan pandangan terhadap agama adalah Karl Max. Marx tidak membuat studi khusus tentang agama sebagaimana 
halnya dengan Max Weber atau Emile Durkheim. Pokok-pokok pikirannya tentang agama tercecer dalam berbagai tulisannya yang mengkritik masyarakat kapitalis. Ada beberapa pokok pikiran marx tentang agama. Pertama, Marx menganggap bahwa agama sebagai suatu alienasi. Dalam hal ini sebenarnya maksud dan tujuan Marx adalah untuk mengkritik masyarakat kapitalis yang telah menimbulkan alienasi dalam diri kaum buruh. Menurut Marx sebagaimana sistem ekonomi kapitalis telah menyebabkan buruh teralienasi, demikian juga agama telah membalikkan perhatian manusia dari situasi real dunia ini dan mengarahkannya kepada dunia sesudah kematian. Menurut marx dalam hal ini agama telah mengubah cara berfikir manusia agar percaya kepada keadaan di luar kenyataan dan dalam agama itu dijelaskan bagaimana cara manusia itu sendiri untuk mencapai sesuatu diluar kenyataan tersebut seperti yang dimaksudkan.

Artinya bahwa di dalam agama ada dijelaskan tentang masih adanya kehidupan lain setelah seseorang itu meninggal.Kehidupan yang dimaksudkan ialah kehidupan kekal yang berasal dari Tuhan. Kalau kita berfikir menurut logika kita masing-masing, sebenarnya tidak mungkin juga kalau ternyata masih ada kehidupan lain setelah terjadinya kematian.Hal ini memang sungguh tidak masuk akal.Tetapi itulah yang dikatakan dalam agama dan kita tidak mungkin menentangnya.Kita juga sebagai umat beragama secara umum percaya akan adanya kehidupan lain setelah kematian tersebut.Dan di dalam agama dijelaskan cara agar kita dapat hidup di kehidupan yang kekal tersebut adalah dengan berbuat baik kepada semua orang,menjalankan perintah Tuhan dan menjauhi larangannya.

Selain itu suatu tindakan dimana berdoa kepada Tuhan untuk memohon keberhasilan hidup tidak disetujui oleh Marx. Karena bagi Marx kemampuan untuk berhasil itu ada di dalam manusia itu sendiri dan tidak perlu berdoa kepada Tuhan untuk memohon keberhasilan yang dimaksud.

Sebenarnya kalau menurut saya maksud dari pernyataan marx tersebut adalah tidak mungkin sesorang itu akan berhasil kalau dia hanya berdoa saja kepada Tuhan tanpa bekerja. Dan dalam hal ini untuk mencapai suatu kesuksesan dan keberhasilan hidup yang dibutuhkan adalah bagimana usaha dan kerja keras kita yang tidak kenal putus asa. Tapi kalau menurut saya kita harusnya berdoa juga kepada Tuhan agar apapun yang kita lakukan dan kerjakan diberkati oleh-Nya,dengan catatan kita berdoa sambil bekerja dan berusaha.

Marx juga mengatakan bahwa ciri-ciri khas yang dikenakan pada Allah sebetulnya tidak lain daripada ciri-ciri khas manusia yang diproyeksikan pada Allah yang mengontrol manusia melalui perintahperintahnya. Oleh karena itu, Marx menambahkan bahwa sebenarnya bukan Allah yang menciptakan manusia menurut gambarnya melainkan manusialah yang menciptakan Allah menurut gambaran atau bayangannya. 
Kalau menurut saya maksud dari pernyataan Marx tersebut yaitu bagaimana mungkin kita bisa percaya dan mengetahui kalau Allah itu menciptakan manusia menurut gambarnya sementara kita juga belum pernah melihat gambar dan rupa Allah seperti apa.Jadi,dalam hal ini artinya manusialah yang membuat Allah itu ada dan manusia percaya kalau Allah itu memang ada sesuai dengan gambaran atau bayangan yang mereka lihat dalam cerita-cerita, film-film dan gambar-gambar tentang Allah.

Kedua, Marx menganggap bahwa agama sebagai sebuah ideologi. Marx mengatakan agama sebagai sebuah ideologi karena banyaknya kenyataan mengenai manusia yang dibalikkan. Maksud pernyataan tersebut menurut saya adalah bahwa agama hanyalah suatu pandangan hidup manusia saja. Manusia percaya akan adanya kehidupan kekal. Sehingga membuat manusia berusaha untuk menjalankan setiap perintah Tuhan dan menjauhi larangannya dengan pernuh kesabaran dan rela menderita dalam menjalani hidup di dunia ini.Dalam hal ini menurut pandangan marx tindakan mereka itu salah,karena mereka lebih mengutamakan Tuhan dan tidak perduli kalaupun mereka harus menderita sehingga pada akhirnya mereka hidup di dalam kemiskinan.Hal ini menurutnya akan merugikan manusia itu sendiri karena lebih mengutamakan hal yang tidak nyata dan mengesampingkan kenyataan yang sebenarnya.

Ketiga, Marx menganggap bahwa agama sebagai candu masyarakat. Artinya agama memiliki ciri-ciri menghibur dan bersifat sementara sebagaimana layaknya obat bius yang memberikan pelepasan sementara dari pendertiaan dengan resiko efek-efek sampingan yang berbahaya. Contohnya dalam kehidupan sehari-hari ketika kita sakit, kita akan minum obat agar sembuh. Dalam hal ini obat berfungsi untuk menghilangkan rasa sakit sementara atau bahkan bisa membawa kesembuhan saat kita mengkonsumsinya. Demikian halnya juga juga dengan agama,dimana agama mengajarkan bahwa ketika kita sabar dan rela menderita demi Tuhan maka kita akan memperoleh kehidupan yang kekal.Disini manusia berfikir bahwa apa yang mereka lakukan telah benar dan merasa terhibur sementara akan apa yang dikatakan dan dijelaskan dalam agama.Sehingga bagi marx,agama itu memiliki ciri-ciri menghibur manusia yang bersifat sementara ketika sedang tertekan ataupun mengalami penderitaan yang mampu membuat mereka sabar dan bertahan menjalani hidup (Hamilton 1995:82).

Keempat, menurut Marx agama harus dihapuskan. Marx menegaskan bahwa agama harus dihapus karena menawarkan kebahagiaan yang bersifat ilusi sebelum mereka mencapai kebahagiaan yang sebenarnya. Maksud dari pernyataan marx ini adalah agama itu sebaiknya dihapus ataupun ditiadakan karena setiap ajaran nya berupa khayalan dan ilusi semata. Sehingga manusia tidak perlu menderita dan tertekan dalam menjalani 
hidup di dunia ini demi mendapatkan kehidupan kekal sesudah adanya kematian yang dianggap tidak nyata.

Namun, agama adalah produk kondisi-kondisi sosial kemasyarakatan, maka ia tidak bisa dihapus. Satu-satunya cara untuk menghapus agama adalah dengan meniadakan kondisi-kondisi yang membawa penderitaan dan kesengsaraan pada hidup manusia. Selain itu menurut Marx, agama tidak mempunyai masa depan. Agama bukanlah sesuatu yang bersifat inheren pada manusia, tetapi produk dari kondisi-kondisi sosial tertentu. Sentimen keagamaan dalam dirinya adalah produk sosial.

Selain Marx, Durkheim juga memiliki beberapa pokok-pokok pikiran tentang agama. Menurutnya agama adalah solidaritas sosial. Dalam bukunya The Elementary Forms of Religious LifeDurkheim mengembang-kan perspektif teoretisnya secara menyeluruh tentang solidaritas sosial. Dalam telaahnya, ia menjelaskan bahwa agama sebagai fakta sosial hadir dalam kesadaran anggota masyarakat, karena gejalanya yang intersubjektif(Durkheim 1947). Bagi Durkheim, analisis sosiologis mengenai agama harus dimulai dengan pengakuan akan adanya saling ketergantungan antara agama dan masyarakat. Pilihannya untuk mempelajari masyarakat sederhana ("masyarakat primitif" menurut terminologi yang dia pakai), dikarenakan sifat ketergantungan ini nampak lebih nyata dibanding dalam konteks masyarakat yang sudah maju. Yang ia lakukan adalah mencari penjelasan tentang gejala agama di masyarakat primitif untuk memahami dasar-dasar kehidupan sosial.

Dengan demikian, bagi Durkheim, dasar-dasar moral dalam masyarakat mempunyai asal-usulnya dalam pengalaman-pengalaman religius kolektif. Kepercayaan-kepercayaan agama dan ritus-ritusnya mencerminkan dan memperkuat kembali struktur sosial masyarakat. Sehingga memudarnya pengaruh agama dalam masyarakat modern mungkin dapat dilihat dengan mudah dalam perspektif Durkheim sebagai satu indikator runtuhnya solidaritas sosial.

Menurut Durkheim, agama yang paling primitif dan paling sederhana itu adalah totemisme. Pertama, Pemahaman Durkheim tentang Totemisme. Menurut Durkheim, simbol-simbol totem ini merupakan lambang dari suku itu sendiri sama seperti bendera merupakan lambang untuk suatu negara. Durkheim lalu menunjukkan bagaimana sistem totem itu merupakan satu sistem kosmologis dan bagaimana kategori-kategori seperti kelas mempunyai kaitan dengan totemisme. Kedua, Durkheim memperhatikan bahwa manusia mengambil bagian di dalam yang sakral. Sebagai anggotaanggota suku yang memiliki totem-totem sakral dan percaya bahwa mereka adalah turunan dari totem-totem yang sakral itu,mereka percaya akan kesakralan dirinya. Ketiga, Menurut Durkheim totemisme yaitu masyarakat menyembah diri sendiri. Dalam hal ini totemisme bukanlah suatu agama yang percaya pada binatang, tumbuhan,manusia ataupun gambar-gambar 
tertentu melainkan kepercayaan pada suatu kekuatan impersonal dan tak bernama yang berada di balik makhluk-makhluk yang dijadikan totem itu sendiri. Karena itu Durkheim menyimpulkan bahwa dewa suku atau totem suku tidak lain daripada masyarakat itu sendiri yang dipersonifikasikan atau dilambangkan dengan tumbuhan atau binatang totem (Durkheim 2003:331).

Max weber tidak berambisi untuk menjawab pertanyaan tentang mengapa orang beragama atau alasan-alasan dari sebuah tingkah laku keagmaaan. Dia tidak tertarik untuk menjelaskan apa itu agama. Namun demikian, Weber juga tetap berusaha untuk mengembangkan sebuah pendekatan umum terhadap agama sebagai suatu fenomena sosial dan meneliti hakikat kehidupan agama itu sendiri.Ada beberapa pokok pikiran Weber tentang agama diantaranya.

Pertama, Pendekatan Psikologis terhadap Agama. Di dalam bukunya yang berjudul The Social Psychology of The World religions, Weber menguraikan pendekatan psikologis terhadap agama. Di dalam buku tersebut, dia menolak pemikiran yang menyatakan bahwa dalam menghubungkan agama dengan faktor-faktor sosial, sesorang harus menggunakan pendekatan yang bersifat reduksionis.

Weber menolak tesis yang mengatakan bahwa agama adalah sebuah ilusi. Weber juga tidak bisa menerima teori-teori tentang agama yang mengatakan bahwa agama merupakan suatu bentuk pelarian dari penderitaan dan kesulitan hidup walaupun dia mengakui adanya hubungan antara agama dan penderitaan.

Menurut Weber, dalam banyak tradisi keagamaan khususnya dalam masyarakat pra-industri, orang-orang yang mengalami kemalangan atau malapetaka berfikir bahwa kemalangan itu disebabkan kemarahan para dewa yang menghukum mereka. Selain itu, mereka juga berfikir bahwa penderitaan atau sakit disebabkan oleh kerasukan roh-roh jahat yang marah akibat perbuatan-perbuatan mereka. Sebenarnya pikiran masyarakat tersebut sudah salah dan terlalu percaya kepada dewa-dewa yang menurut mereka ada.

Kedua, Pokok pikiran Weber tentang agama pada suku-suku asli. Dimana dalam hal ini Weber mengamati bahwa motivasi tingkah laku keagamaan pada masyarakat sederhana umumnya adalah keinginan untuk mempertahankan hidup dan memperoleh kesejahteraan. Kepercayaan dan tingkah laku keagamaan serta tindakan-tindakan magis tidak bisa dipisahkan dari kehidupan sehari dan hampir selalu terarah pada tujuantujuan ekonomis,yakni kesejahteraan hidup secara material.

Weber sering kali membuat perbedaan antara tindakan magis dan tingkah laku keagamaan. Menurut dia, tindakan magis umumnya bersifat manipulatif dan cenderung memaksa dewi-dewi atau roh-roh halus untuk melakukan apa yang diinginkannya. Sementara itu,tingkah laku keagamaan 
atau agama terarah kepada penyembahan dewa-dewi itu. Menurut Weber, agama-agama pada masyarakat asli cenderung terarah kepada hal-hal yang bersifat magis. Artinya dalam hal ini masyarakat sangat percaya kepada dewa-dewi bahwa dewa akan melakukan apa yang mereka inginkan.

Ketiga, Pokok pikiran Weber tentang agama dan rasionalitas. Dalam kehidupan keagamaan, rasionalitas berarti menghilangkan aspek-aspek magis dalam praktik kehidupan keagamaan dan mengembangkan ajaranajaran agama ke dalam satu sistem doktrin yang bersifat formal. Dalam upaya mengembangkan agama ke dalam sistem doktrin yang bersifat formal dikembangkanlah bermacam disiplin ilmu yang berhubungan dengan agama.Weber meyakini bahwa ajaran-ajaran agama mempunyai pengaruh terhadap tingkah laku manusia dan dia berminat untuk mengetahui dampak dari ajaran-ajaran agama itu terhadap aktivitas ekonomi (Raho 2013:98).

Sementara menurut Peter L. Berger, Agama sebagai hasil konstruksi manusia melalui tiga tahap dialektik, yaitu eksternalisasi, objektivasi, dan internalisasi(Berger 1967:88). Inti dari ketiga momentum proses dialektis ini adalah bahwa manusia melalui tindakan dan interaksinya secara terus menerus menciptakan suatu realitas sosial yang dimiliki bersama, termasuk realitas yang dialami sehari-hari. Berger memahami agama sebagai bentuk proyeksi manusia yang dihasilkan lewat eksternalisasi (Berger 1967:180). Rumusan Berger tentang agama ini bisa menjadi titik-acuan bagi kajian empiris terhadap agama, yang tentunya berada di luar kajian teologis dan etis. Melalui proses sosialisasi, agama melakukan pelanggengan dunia yang telah dikonstruksikan manusia. Di samping itu, agama melegitimasi realitas sosial yang ada. Agama membutuhkan struktur plausibilitas atau basis sosial guna mendukung keberadaannya.

Dengan demikian agama sangat berperan dalam membentuk perilaku masyarakat, dan mampu membangun kesadaran manusia untuk bertindak sesuai dengan dinamika nilai dalam masyarakat. Sekali lagi, dalam konteks ini,agama yang berintikan iman (belief) akan mengarahkan bahkan membentuk perilaku masyarakat (practice). Beliefyang dalam ranah sosiologis dikategorikan sebagai sesuatu yang abstrak dan berada dalam wilayah kesadaran (mind) akan mendeterminasi perilaku dan tindakan (matter) yang dilakukan oleh manusia, baik sebagai individu atau masyarakat dalam wilayah nyata.

Ketika masyarakat merupakan "realitas" bagi manusia - masyarakat adalah "buatan" manusia dan di sisi lain manusia sebagai pembangun masyarakat dan dunia, dan manusia merupakan "subjek" yang beragama, maka sesuai dengan pemikiran konstruksionis Berger (dan Luckmann), agama akan mendeterminasi pranata sosial yang lahir dan berada dalam masyarakat, yang tentu saja tidak mengeliminir elemen pembentuk lain seperti struktur sosial yang telah ada. Agama telah menjelma menjadi bentuk norma dan perilaku sekaligus, dan ia menjadi sebuah gejala budaya, 
di satu sisi, serta menjadi sistem budaya di sisi lain. Dalam konteks ini, apa yang diungkapkan Clifford Geertz bahwa agama menjadi sistem budaya (cultural system), sejalan dengan konsep Berger tentang "kehadiran" Tuhan dalam masyarakat (theodicy) (Berger 1967:53).

\section{Kejahatan dan Campur Tangan Tuhan dalam Perspektif Teodesi dan Teologi Islam}

Menurut pandangan Berger (1990) teodisi mempengaruhi secara langsung setiap individu dalam kehidupannya sehari-hari di masyarakat. Salah satu fungsi sosial penting teodisi adalah sebagai penjelasan hak kesetaraan dalam sebuah kekuasaan dan keistimewaan yang diperoleh seorang manusia dari Tuhan(Berger 1967:58-59).

Berger menggunakan konsep Teodisi untuk memberikan makna terhadap penderitaan yang dialami manusia di dunia, dengan sekaligus menjanjikan kebahagiaan 'di dunia sana'. Dalam hubungan ini agama jelas merupakan sebuah kekuatan alienasi. Alienasi oleh Berger dimengerti sebagai terputusnya hubungan dialektik antara individu dengan dunianya. Meski sebaliknya agama juga memiliki kekuatandealienasi.

Sejalan dengan perkembangan masyarakat modern, Berger melihat proses sekularisasi sebagai lepasnya berbagai sektor kehidupan masyarakat dari dominasi institusi dan simbol agama. Sedang sekularisasi itu sendiri berakar pada tradisi masyarakat Israel kuno sebagaimana tertuang dalam Perjanjian Lama. Hal ini jelas terlihat dalam konsep transendentalisasi Tuhan, motif historisasi dan rasionalisasi etis yang sangat mewarnai Perjanjian Lama.

Gambaran serupa juga terjadi pada diri seorang agamawan, filsuf, ilmuwan dan orang yang tidak beragama sekalipun ketika memandang pengalaman dan nilai-nilai pada dataran religius eksistensial. Seorang ateis akan mengatakan bahwa kejahatan termasuk persoalan yang bertentangan dengan keadilan Tuhan. Sedangkan kaum politeis, sebagaimana kaum dualis, akan berpendapat bahwa jika ada kejahatan dan kebaikan maka mereka meniscayakan adanya dua sumber wujud/Tuhan(Abrahamov 1998:59). Artinya, setiap kejahatan dan kebaikan, masing-masing akan berhubungan dengan sumber atau pencipta yang berbeda. Tetapi, dalam dunia monoteis, meskipun dualitas itu masih ada, kebaikan tetap sebagai entitas tunggal. Sebaliknya, dalam kesadaran mistik, kejahatan lenyap sama sekali dan yang tinggal hanya kebaikan, yaitu Tuhan (Muthahhari 1997:12324).

Karena itu, sebelum membahas lebih jauh tentang persoalan teodisi perlu mengurai hakikat kejahatan. Apakah kejahatan merupakan persoalan eksistensial dan realistis ataukah persoalan noneksistensial dan relatif? Meski jawabannya beragam, namun bagi kaum ateis, politeis dan dualis, jawabnya sama bahwa kejahatan memiliki esensi, bahkan termasuk sifat- 
sifat buruk atau jahat; seperti pembohong, bakhil, khianat dan sebagainya merupakan sifat-sifat riil pada manusia, dan sifat tersebut sekaligus merupakan esensinya. Kaum ateis memandang bahwa nilai merupakan salah satu aspek dari pengalaman sehingga kejahatan sebagai suatu nilai harus pula digali dari pengalaman. Dengan kata lain, nilai kejahatan tidak akan pernah ada jika ia tidak termanifestasikan secara eksistensial di lapangan (Mackie, John Leslie 1982:52).

Sementara itu, kaum dualis, meski juga menegaskan adanya hakikat wujud kejahatan, sebenarnya hendak membebaskan Tuhan dari kejahatan. Tetapi, dengan penegasannya itu mereka bukan saja telah menyekutukan Tuhan dengan wujud lain sebagai pembuat kejahatan, bahkan telah mereduksi kehendak dan kekuasaan Tuhan yang tak terbatas sebagai pencipta kebaikan semata. Pandangan ini di antaranya tercermin pada diri Leibniz yang berpendapat bahwa Tuhan tidak dapat melakukan sesuatu yang secara logis tidak mungkin, walaupun ia segera memberi catatan bahwa fakta ini sama sekali tidak mengandung pengertian membatasi kemahakuasaan Tuhan (McCloskey 1974:14).

Lain halnya dengan Muthahhari yang menggunakan pendekatan Mu'tazilah dan kaum filsuf Muslim seperti Ibnu Sina dan Mulla Shadra. Dia mengatakan bahwa ketika Islam memandang alam, ia memandangnya dalam dua entitas yang berbeda; kebaikan dan kejahatan. Tetapi, dalam kerangka pemahaman yang lebih luas, alam ini dipandang sebagai zero kejahatan. Semua yang ada adalah baik karena sistem yang mendasarinya adalah sistem yang terbaik. Dari perspektif dalil ontologis Ibnu Sina, esensi semesta alam dan segala yang ada di dalamnya adalah kebaikan, suatu keniscayaan dari wujud Tuhan sebagai wajib al-wujud bi dhatihi (ada berdasarkan dirinya sendiri).

Jika wujud Tuhan merupakan wujud yang niscaya, maka kemahabaikan dan kemahaadilan-Nya merupakan sifat yang niscaya pula. Sebaliknya, segala yang ada selain Tuhan dari segi esensinya adalah mumkin al-wujud, mungkin bisa ada dan mungkin tidak. Artinya, kebaikan dan kejahatan yang ada di dunia merupakan sesuatu yang mungkin. Mereka menjadi ada karena memperoleh limpahan wujud dari wajib al-wujud, tetapi karena Tuhan itu Maha Baik, Maha Adil dan Maha Sempurna serta mustahil bersifat sebaliknya, maka segala yang melimpah dari-Nya pada esensinya adalah kebaikan. Dengan demikian, kejahatan yang ada di dunia adalah non-eksistensial dan relatif karena secara fundamental esensinya adalah kebaikan.

Berangkat dari pemikiran filosofis di atas, dapat dikatakan bahwa pernyataan "kejahatan di dunia bersifat eksistensial dan noneksistensial" adalah sama-sama mengandung kebenaran. Kejahatan dikatakan noneksistensial tidak berarti bahwa kejahatan yang ada di masyarakat tidak ada wujudnya karena hal itu bertentangan dengan kemestian. Kenyataannya 
benar-benar disaksikan adanya kebutaan, ketulian, kemiskinan, penyakit, kezaliman, penganiayaan, kebodohan, kelemahan, kematian, gempa bumi, yang semua itu tidak dapat diingkari sebagai sesuatu yang jahat. Dalam hal ini menarik untuk mencermati pernyataan Muthahhari (Muthahhari 1997:1558), bahwa:

"Kebaikan dan kejahatan di alam ini bukan dua hal yang berbeda dan terpisah satu sama lain, sebagaimana berbedanya benda-benda mati dari tumbuhtumbuhan, atau tumbuh-tumbuhan dari binatang, yang masing-masing memiliki barisan tertentu. Adalah kekeliruan jika membayangkan bahwa kejahatan memiliki barisan tertentu yang esensinya bersifat "jahat sejati" tanpa sedikit pun kebaikan di dalamnya, dan bahwa kebaikan memiliki barisan tertentu yang berbeda dan esensinya bersifat "baik sejati" tanpa sedikit pun kejahatan di dalamnya. Yang benar adalah bahwa kebaikan dan kejahatan merupakan dua hal yang menyatu tanpa bisa dipisah-pisahkan. Ketika di suatu bagian alam ada kejahatan, di situ pasti ada kebaikan, dan di mana ada kebaikan pasti di situ ada kejahatan. Kebaikan dan kejahatan begitu menyatu dan bersenyawa di alam ini, bukan senyawa kimiawi melainkan senyawa yang lebih mendalam dan lebih halus, senyawa antara eksistensi dan non-eksistensi (tarkibal-wujud wa al'adam)".

\section{Penutup}

Dari pembahasan di atas dapat ditegaskan kembali bahwa dualisme wujud, yakni kejahatan dan kebaikan, pada dataran fenomenalnya memang ada, tetapi pada esensinya hanya ada kebaikan. Pandangan ini merupakan konsekuensi dari kenyataan bahwa Tuhan sebagai wajib al-wujud adalah Maha Baik, Maha Adil dan Maha Sempurna sehingga apa pun yang melimpah dari-Nya pasti mengandung esensi kebaikan. Dalam hal ini Muthahhari menegaskan bahwa pada dataran fenomena tidak ada "kejahatan sejati" maupun "kebaikan sejati", sedang pada dataran noumena hanya ada satu esensi, yakni kebaikan, karena substansi kejahatan benarbenar merupakan ketiadaan murni.

Sementara Berger menggunakan konsep Teodisi untuk memberikan makna terhadap penderitaan yang dialami manusia di dunia, dengan sekaligus menjanjikan kebahagiaan 'di dunia sana'. Dalam hubungan ini agama jelas merupakan sebuah kekuatan alienasi. Alienasi oleh Berger dimengerti sebagai terputusnya hubungan dialektik antara individu dengan dunianya. Menurut Berger teodisi mempengaruhi secara langsung setiap individu dalam kehidupannya sehari-hari di masyarakat. Salah satu fungsi sosial penting teodisi adalah sebagai penjelasan hak kesetaraan dalam sebuah kekuasaan dan keistimewaan yang diperoleh seorang manusia dari Tuhan. 
Syafieh

\section{DAFTAR PUSTAKA}

Abrahamov, Benyamin. 1998. Imu Kalam: Tradisonalisme Dan Rasionalisme Dalam Teologi Islam. Jakarta: Serambi.

Al-Baghdadi, Abu Mansur bin Muhammad. n.d. Al-Farq Baina Al-Firaq. Kairo: Maktabah Ibn Sina.

Al-Jabbar, Abd. 1965. Syarh Al-Ushul Al-Khamsah. edited by 'Abd alKarim 'Usman. Kairo: Maktabah Wahbah.

Bagus, Lorens. 2002. Kamus Filsafat. Jakarta: Gramedia Pustaka Utama.

Bakar, Osman. 1994. Tauhid Dan Sains: Esai-Esai Tentang Sejarah Dan Filsafat Sains Islam. Bandung: Pustaka Hidayah.

Berger, Peter Ludwig. 1967. The Sacred Canopy: Elements of a Sociological Theory of Religion. New York: Anchor Books.

Berkhof, Louis. 1981. Systematic Theology. USA: W.M.B. Eermands Publishing.

Durkheim, Emile. 1947. The Elementary Forms of Religious Life. New York: Free Press.

Durkheim, Emile. 2003. Sejarah Agama. Yogyakarta: Ircisod.

Hamilton, Malcolm B. 1995. The Sociology of Religion. London: Routledge.

Leahy, Louis. 1993. Filsafat Ketuhanan Kontemporer. Yogyakarta: Kanisius.

Mackie, John Leslie, and J. L. MacKie. 1982. The Miracle of Theism: Arguments for and against the Existence of God. Oxford: Clarendon Press.

McCloskey, H. J. 1974. "The Morality of Punishment of the'Moral'Criminal." in Punishment and Human Rights. Cambridge: Schenkman Pub. Co.,.

Muthahhari, Murtadha. 1997. Hak-Hak Wanita Dalam Islam. Jakarta: Lentera. Nasution, Harun. 1986. Akal Dan Wahyu Dalam Islam. Jakarta: UI-Press.

Nasution, Harun. 1991. Filsafat Agama. Jakarta: Bulan Bintang.

Raho, Bernard. 2013. Agama Dalam Perspektif Sosiologi. Jakarta: Obor.

Schneider, Laurel C., and Cassie JE Trentaz. 2008. "Making Sense of Feminist Theology Today." Religion Compass 2.5:788-803. 